\title{
Pancreatic cellular infiltrates in autoimmune-prone New Zealand Black mice
}

\author{
T.A. Seemayer ${ }^{1}$ and E. Colle ${ }^{2}$ \\ Departments of ${ }^{1}$ Pathology and 2 Pediatrics, The Montreal Children's Hospital and McGill University - \\ Montreal Children's Hospital Research Institute, Montréal, Québec, Canada
}

\begin{abstract}
Summary. Healthy New Zealand Black (NZB) mice of both sexes (age 19-31 weeks) were studied to determine the magnitude of pancreatic $\beta$ cell injury related to mononuclear cell infiltration of islets. This investigation was undertaken following the description of spontaneous cellular immune reactions against islets in four strains of autoimmune-prone mice, including NZB mice [1]. Studies included complete autopsies with histological examination, determination of the pancreatic content of immunoreactive insulin, and the measurement of the plasma glucose concentration. Mononuclear cell infiltrates were identified in the lung, liver, kidney, salivary gland, mesentery, and pancreas. In the latter site, the infiltrates were situated in fibrous septae about ducts, ductules, and venules
\end{abstract}

rather than islets. Only islets contiguous to infiltrates were involved, and then but focally. Insulitis, as manifest by the envelopment and permeation of islets by mononuclear cells, was not observed. In none was there a significant reduction of $\beta$ cells or pancreatic insulin content, neither was hyperglycaemia manifest. This study reveals that, although NZB mice are subject to autoimmune phenomena and widespread mononuclear cell infiltrates, $\beta$ cell injury and insulitis are not consistent features of this strain.

Key words: New Zealand Black mice, diabetes mellitus, autoimmunity, pancreatic cellular infiltrates.
The New Zealand Black (NZB) mouse has served as a model for a variety of autoimmune conditions. Originally derived from agouti mice following inbreeding for coat colour [2], NZB mice develop spontaneously (as a function of ageing) severe autoimmune haemolytic anaemia [3], mild immune complex glomerulonephritis [4], and various expressions of $\beta$ cell lymphoproliferation, including lymphoma [5]. The intense study of this strain, as well as the Fl hybrid derived from the black (NZB) and white (NZW) strain, the animal model for systemic lupus erythematosus [6], has generated a wealth of information related to the ontogeny, regulation, and ageing of the immune system [7]. Although prone to age-related illnesses, the NZB mouse has not been described to develop diabetes mellitus, even though a related strain, the New Zealand Obese mouse, serves as a model of autoimmune-mediated, adult-type insulin-resistant diabetes [8].

A recent report described spontaneous cellular immune reactions against pancreatic islets with $\beta$ cell destruction in NZB, $(\mathrm{NZB} \times \mathrm{NZW})$ Fl hybrids, MRL, and BXSB mice [1]. The latter three strains manifest many autoimmune phenomena which include polyclonal $\beta$ cell lymphoproliferation, the formation of autoanti- bodies and circulating immune complexes, abnormalities of Ig and complement, and a severe immune complex glomerulonephritis [9]. This report was provocative since spontaneous immune reactions against islets and $\beta$ cells are uncommon events in mice, one notable exception represented by the non-obese diabetic mouse [10]. Intrigued by this finding, we undertook a study to assess the magnitude of pancreatic $\beta$ cell injury in autoimmune-prone mice. Since the index report detailed islet lymphocytic infiltrates in $80 \%$ of NZB mice, $50 \%$ of $(\mathrm{NZB} \times \mathrm{NZW}) \mathrm{Fl}$ hybrids and MRL mice, and less than $20 \%$ of BXSB mice, the NZB strain was chosen as our experimental model. Moreover, since adult mice had been reported to show a more intense form of insulitis than younger animals [1], we elected to study adult animals.

\section{Materials and methods}

\section{Animals}

Mice of both sexes of the NZB/BINJ strain were utilized at 19-31 weeks of age. Controls were represented by male and female $\mathrm{BALB} / \mathrm{cJ}$ mice, aged 15-27 weeks, and male and female CBA mice, 

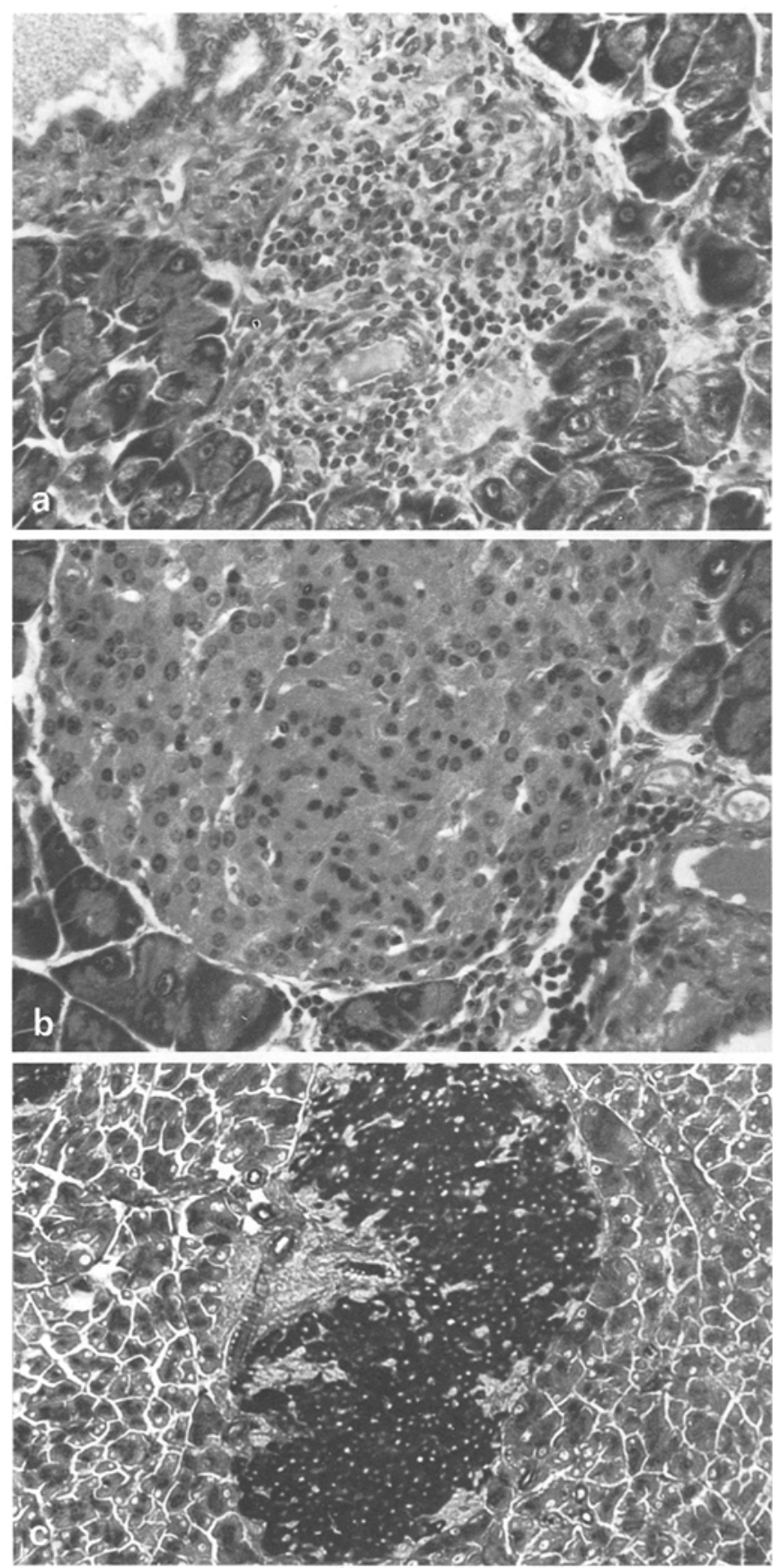

Fig. a-c. Photomicrographs of: a focus of intense pancreatic periductular and perivascular mononuclear cell infiltration (haematoxylinphloxine-saffron, $\times 162$ ); b pancreas demonstrating normal islet with minute focus of mononuclear cell infiltration at vascular pole (haematoxylin-phloxine-saffron, $\times 162$ ); $\mathbf{c}$ islet with cellular infiltrate at vascular pole stained with aldehyde fuchsin technique illustrating wellgranulated $\beta$ cells (Gomori aldehyde fuchsin stain, $\times 81$ ). This pattern of islet staining respresented a consistent finding

aged 28 weeks. The NZB/BINJ and BALB/cJ mice were purchased from the Jackson Laboratories, Bar Harbor, Maine, USA. The CBA mice were donated from the colony of Professor W.S. Lapp, Department of Physiology, McGill University, Montreal. All animals received standard laboratory chow and water ad libitum and appeared healthy.

\section{Study design}

At intervals, animals (15-31 weeks of age) were killed with ether and tissue and plasma were obtained for analysis. All studies were performed on coded specimens.

\section{Histology}

Tissue from complete autopsies was fixed in $10 \%$ buffered formalin, except the pancreas which was fixed in Bouin's solution. Paraffin-embedded sections were stained by haematoxylin-phloxine-saffron and examined by light microscopy. Pancreatic sections were stained, as well, by the Gomori aldehyde fuchsin technique for $\beta$ cells [11]. Approximately $90 \%$ of the pancreas was submitted for histological study; the remaining $10 \%$ (tail of pancreas adjacent to the spleen) was employed for insulin assay (vide infra). A minimum of ten step-sections was examined from each block of pancreatic tissue.

\section{Tissue extraction and hormone assays}

A portion of pancreas (approximately 10\%) was excised, blotted, weighed, and placed in acid-alcohol solution. The piece was homogenized and left overnight at $3{ }^{\circ} \mathrm{C}$. The homogenate was centrifuged at $4000 \mathrm{rev} / \mathrm{min}$ for $30 \mathrm{~min}$ and the supernatant was stored at $-20^{\circ} \mathrm{C}$ until assayed. Blood was collected in heparinized tubes from the orbital sinus. Plasma was separated and the samples were stored at $-20^{\circ} \mathrm{C}$. Pancreatic immunoreactive insulin (IRI) concentration was determined as described previously [12]. Plasma glucose was measured by an automated glucose oxidase method (Beckman glucose analyzer 2; Beckman Instruments, Fullerton, California, USA).

\section{Statistical analyses}

The values of pancreatic IRI and plasma glucose from NZB mice were compared with those from control mice. Similarly, values from these two determinations were compared among NZB animals with and without pancreatic mononuclear cell infiltration. The data were analyzed by Student's t-test. A $p$ value of $>0.05$ was considered to be significant.

\section{Results}

\section{Histology}

Sections from all 16 control mice disclosed normal histology in all tissues. No cellular infiltrates were recognized in the pancreas; islets maintained a normal complement of $\beta$ cells as judged from aldehyde fuchsinstained sections.

Sections from 21 NZB mice disclosed mononuclear cell infiltrates in the lung (13 animals), liver (four animals), kidney (four animals), and salivary gland (three animals). The infiltrates were disposed about bronchi, bronchioles, ducts, ductules, and/or venules. Megakaryocytic hyperplasia was manifest in the spleen; follicular hyperplasia was noted in lymph nodes; no consistent alterations were recognized in the thymus. In several animals, nodular lymphoid aggregates were noted in mesenteric fat adjacent to the pancreas. In eight animals, discrete mononuclear cell infiltrates were distributed in fibrous septae about pancreatic ducts, ductules, veins, and venules (Fig. 1 a). When infiltrates were identified in relation to islets (an uncommon occur- 
rence), the involvement of islets was focal, contiguous to the affected ductule, and/or venule (Fig. 1b). Envelopment and extensive permeation of islets by mononuclear cells was not noted. Aldehyde fuchsin-stained sections revealed a normal complement of $\beta$ cells in islets (Fig. $1 \mathrm{c}$ ), even those contiguous to ductular and/or venular cellular infiltrates.

\section{Pancreatic immunoreactive insulin measurements}

Pancreatic IRI concentrations varied widely in both the NZB and the control strains, but all animals had levels above those consistently found in overtly diabetic rodents. The mean concentrations were higher in the NZB mice $(294.7 \pm 27.2 \mathrm{ng} / \mathrm{mg})$ than in the BALB/cJ $(190.4 \pm 45.1 \mathrm{ng} / \mathrm{mg})$ and the CBA groups $(261.9 \pm$ $20.6 \mathrm{ng} / \mathrm{mg}$ ), but the differences did not achieve statistical significance. Within the NZB group, the mean value in those animals in which pancreatic infiltrations were noted was higher than in animals with normal histology $(317.7 \pm 51.4$ versus $280.5 \pm 29.7 \mathrm{ng} / \mathrm{mg})$, but again, the difference was not statistically significant.

\section{Plasma ghucose measurements}

There was no difference in the mean value of plasma glucose between the BALB/cJ $(5.3 \pm 0.3 \mathrm{mmol} / 1)$ and the NZB $(5.7 \pm 0.3 \mathrm{mmol} / 1)$ groups; values were somewhat higher in the CBA strain $(8.3 \pm 0.2 \mathrm{mmol} / 1)$. No significant differences were noted between the NZB animals with pancreatic lesions $(5.96 \mathrm{mmol} / \mathrm{l})$ and those with a normal pancreas $(5.59 \mathrm{mmol} / \mathrm{l})$. Pancreatic histology, pancreatic IRI concentrations, and plasma glucose concentrations are presented in Table 1.

\section{Discussion}

This study demonstrates that autoimmune-prone NZB mice develop diffuse mononuclear cell infiltrates in a variety of tissues including lung, liver, salivary gland, mesentery, and pancreas. In the latter site, the infiltrates are centred in fibrous septae about ducts, ductules, and venules. Rarely, islets may be affected, but then, involvement is focal, related to that portion of the islet contiguous to affected ducts, ductules, and/or venules. The pattern of insulitis in human [13] and experimental [14-16] insulin-dependent diabetes mellitus characterized by mononuclear cell envelopment and extensive penetration of islets was not noted in this study. Moreover, histochemical stains for pancreatic $\beta$ cells and radioimmunoassay determinations of pancreatic insulin content suggest that no major immunological assault is directed towards $\beta$ cells.

The involvement of ductular and venular pancreatic structures in NZB mice is not dissimilar from that described experimentally in mice following the adminis-
Table 1. Pancreatic histology, pancreatic IRI and plasma glucose concentrations in control and experimental NZB/BINJ mice

\begin{tabular}{|c|c|c|c|c|c|}
\hline Strain & $\begin{array}{l}\text { Age } \\
\text { (weeks) }\end{array}$ & Sex & $\begin{array}{l}\text { Pancreatic } \\
\text { histology }\end{array}$ & $\begin{array}{l}\text { Pancreatic } \\
\text { IRI (ng/mg } \\
\text { wet weight) }\end{array}$ & $\begin{array}{l}\text { Plasma } \\
\text { glucose } \\
(\mathrm{mmol} / \mathrm{l})\end{array}$ \\
\hline \multicolumn{6}{|c|}{ Control mice } \\
\hline $\mathrm{BALB} / \mathrm{cJ}$ & 27 & M & Normal & 236.6 & 5.3 \\
\hline \multirow[t]{5}{*}{$(n=6)$} & 23 & M & Normal & 380.8 & 4.8 \\
\hline & 19 & $\mathbf{M}$ & Normal & 194.8 & 4.1 \\
\hline & 19 & $\mathrm{~F}$ & Normal & 65.6 & 6.4 \\
\hline & 15 & $\mathrm{~F}$ & Normal & 53.5 & 4.8 \\
\hline & 15 & M & Normal & 211.2 & \\
\hline \multicolumn{4}{|c|}{ Mean \pm SEM } & $190.4 \pm 45.1$ & $5.3 \pm 0.3$ \\
\hline CBA & 28 & $\mathrm{~F}$ & Normal & 162.3 & 7.6 \\
\hline \multirow[t]{9}{*}{$(n=10)$} & 28 & $\mathbf{F}$ & Normal & 208.4 & 8.2 \\
\hline & 28 & $\mathrm{~F}$ & Normal & 205.5 & 8.0 \\
\hline & 28 & $\mathrm{~F}$ & Normal & 283.2 & 8.6 \\
\hline & 28 & $\mathrm{~F}$ & Normal & 205.3 & 8.9 \\
\hline & 28 & M & Normal & 376.3 & 7.6 \\
\hline & 28 & M & Normal & 260.1 & 7.9 \\
\hline & 28 & M & Normal & 279.6 & 9.4 \\
\hline & 28 & $\mathrm{M}$ & Normal & 356.2 & 7.4 \\
\hline & 28 & $\mathrm{M}$ & Normal & 282.4 & 8.9 \\
\hline \multicolumn{4}{|c|}{ Mean \pm SEM } & $261.9 \pm 20.6$ & $8.3 \pm 0.2$ \\
\hline \multicolumn{6}{|c|}{ Experimental mice } \\
\hline $\mathrm{NZB} /$ & 31 & M & Normal & 337.2 & 3.9 \\
\hline BINJ & 31 & M & One focus PVI & 194.8 & 5.4 \\
\hline \multirow[t]{20}{*}{$(n=21)$} & 31 & $\mathrm{~F}$ & Two foci PDI & 276.7 & 6.2 \\
\hline & 27 & $\mathrm{~F}$ & One focus PDI & 259.5 & 5.3 \\
\hline & 27 & M & Normal & 225.6 & 6.3 \\
\hline & 27 & M & $\begin{array}{l}\text { One focus PDI } \\
\text { with partial in- } \\
\text { volvement of islet }\end{array}$ & 266.7 & 6.0 \\
\hline & 27 & $M$ & Normal & 176.8 & 6.7 \\
\hline & 27 & $\mathrm{~F}$ & Normal & 391.0 & 5.9 \\
\hline & 27 & $\mathrm{~F}$ & Normal & 202.3 & 6.7 \\
\hline & 23 & $\mathrm{M}$ & $\begin{array}{l}\text { One massive focus } \\
\text { PDI with partial } \\
\text { islet involvement }\end{array}$ & 679.6 & 6.3 \\
\hline & 23 & $\mathrm{~F}$ & One focus PDI & 229.7 & 6.2 \\
\hline & 23 & $\mathrm{~F}$ & Normal & 266.3 & 3.1 \\
\hline & 23 & M & One focus PDI & 380.4 & 4.9 \\
\hline & 23 & $\mathbf{M}$ & Normal & 304.7 & 6.4 \\
\hline & 23 & $\mathrm{~F}$ & Normal & 424.2 & 6.4 \\
\hline & 19 & $\mathrm{~F}$ & One focus PDI & 254.1 & 7.4 \\
\hline & 19 & $\mathrm{~F}$ & Normal & 335.2 & 7.5 \\
\hline & 19 & $\mathrm{~F}$ & Normal & 222.9 & 5.9 \\
\hline & 19 & $\mathbf{M}$ & Normal & 177.0 & 4.0 \\
\hline & 19 & $\mathbf{M}$ & Normal & 97.7 & 2.6 \\
\hline & 19 & $\mathbf{M}$ & Normal & 485.5 & 7.3 \\
\hline & \multicolumn{3}{|c|}{ Mean \pm SEM } & $294.7 \pm 27.2$ & $5.7 \pm 0.3$ \\
\hline
\end{tabular}

$\mathrm{PDI}=$ periductal or periductular mononuclear cell infiltration $\mathrm{PVI}=$ perivascular mononuclear cell infiltration

tration of anti-insulin serum [17] and after the induction of acute graft-versus-host reactions [18]. In graft-versushost systems, both acute and chronic reactions result in the apparent homing of mononuclear cells to a variety of lymphoid and non-lymphoid targets. Depending on the system employed, epithelial injury is seen in the skin, gut, thymus, bronchi, and ductules of various tissues including liver, salivary gland, breast, and skin [19]. Others have described that acute graft-versus-host reactions may result in cellular immune reactions against islets with resultant $\beta$ cell necrosis [20]. In our experience, pancreatic infiltration appears largely related to ducts, 
ductules, and venules, with little direct involvement of islets. During the reaction, Ia antigens are expressed on certain epithelial cells which are normally negative for this antigen [21]. It is postulated, though not yet proven, that these newly expressed Ia antigens on target cells may serve as recognition units for effector cells responsible for tissue injury during the graft-versus-host reaction [19]. Whether a similar mechanism accounts for the distribution of mononuclear cell infiltrates in NZB mice is unknown.

Acknowledgements. The authors sincerely appreciate the excellent assistance of A. Lee Foon, L. Pegorari, M. Ranger, and R. Grab. This work was supported in part by grants from the Medical Research Council of Canada, the National Cancer Institute of Canada, the Juvenile Diabetes Foundation, and the McGill University - Montreal Children's Hospital Research Institute. Dr. Seemayer is a McPherson, Fraser, Monat Associate of McGill University.

\section{References}

1. Kolb H, Freytag G, Kiesel U, Kolb-Bachofen V (1980) Spontaneous autoimmune reactions against pancreatic islets in mouse strains with generalized autoimmune disease. Diabetologia 19: 216-221

2. Bielschowsky M, Goodall CM (1970) Origin of inbred NZ mouse strain. Cancer Res 30: 834-836

3. Bielschowsky M, Helyer BJ, Howie JB (1959) Spontaneous hemolytic anaemia in mice of the NZB/Bl strain. Proc Univ Otago Med School 37:9-11

4. Hicks JD, Burnet FM (1966) Renal lesions in the "autoimmune" mouse strains NZB and NZB $\times$ NZW. J Pathol Bacteriol 91: $467-477$

5. East $\mathbf{J}$ (1970) Immunopathology and neoplasms in New Zealand black (NZB) and SJL/J mice. Prog Exp Tumor Res 13: 84-134

6. Talal N, Steinberg AD (1974) The pathogenesis of autoimmunity in New Zealand black mice. Curr Top Microbiol Immunol 64: 79-103

7. Talal N (1977) Autoimmunity. New York, Academic Press, p 183

8. Melez KA, Harrison LC, Gillian JN, Steinberg AD (1980) Diabetes is associated with autoimmunity in the New Zealand Obese (NZO) mouse. Diabetes 29: 835-840

9. Andrews BS, Eisenberg RA, Theofilopoulos AN, Izui S, Wilson C,
McConahey PJ, Murphy ED, Roths JB, Dixon FJ (1978) Spontaneous murine lupus-like syndromes: clinical and immunopathological manifestations in several strains. J Exp Med 148: 1198-1215

10. Makino S, Kunimoto K, Muraoka Y, Katagirl K, Tochino Y (1980) Breeding of a non-obese, diabetic strain of mice. Exp Anim 29: $1-13$

11. Gomori G (1950) Aldehyde-fuchsin: new stain for elastic tissue. Am J Clin Pathol 20: 665-666

12. Tannenbaum GS, Colle E, Wanamaker L, Gurd W, Goldman H, Seemayer, TA (1981) Dynamic time-course studies of the spontaneously diabetic BB Wistar rat. II. Insulin-, glucagon-, and somotostatin-reactive cells in the pancreas. Endocrinology 109: $1880-1887$

13. Gepts W (1965) Pathologic anatomy of the pancreas in juvenile diabetes mellitus. Diabetes 14: 619-633

14. Craighead JE, McLane MFB (1968) Diabetes mellitus: induction in mice by encephalomyocarditis virus. Science 162:913-914

15. Like AA, Rossini AA (1976) Streptozotocin-induced pancreatic insulitis: new model of diabetes mellitus. Science 193:415-417

16. Nakhooda AF, Like AA, Chappel CI, Murray FT, Marliss EB (1977) The spontaneously diabetic Wistar rat: metabolic and morphologic studies. Diabetes 26: 100-112

17. Freytag G (1968) Histologische und radioautographische Untersuchungen am Inselsystem der Maus beim Insulinantikörper-Diabetes. Beitr Pathol Anat Allg Pathol 137: 121-148

18. Seemayer TA, Gartner JG, Colle E, Lapp WS (1983) Acute graftversus-host reaction in the pancreas. Transplantation 35: 72-77

19. Seemayer TA, Gartner JG, Lapp WS (1983) The graft-versus-host reaction. Human Pathol 14: 3-5

20. Kolb H, Freytag G, Kiesel U, Kolb-Bachofen V (1981) Cellular immune reactions against pancreatic islets as a consequence of graft-versus-host disease. Clin Exp Immunol 43: 121-129

21. Lampert IA, Smitters AJ, Chisholm PM (1981) Expression of Ia antigen on epidermal keratinocytes in graft-versus-host disease. Nature 293: 149-151

Received: 25 August 1983

and in revised form: 9 January 1984

Dr. Thomas A. Seemayer

Department of Pathology

Montreal Children's Hospital

2300 Tupper Street

Montreal, Quebec H3H 1P3

Canada 